\title{
Hydrozetes species (Acari, Oribatida) at bog ponds and pools in the Tatra National Park and Orawa-Nowy Targ Basin (Kotlina Orawsko-Nowotarska) in southern Poland
}

\author{
MARCIN MISTRZAK, ANNA SENICZAK and STANISŁAW SENICZAK
}

Department of Ecology, University of Technology and Life Sciences, Ks. Kordeckiego 20, 85-225 Bydgoszcz, Poland

Corresponding author: Anna Seniczak, aseniczak@utp.edu.pl

(Received on 21 May 2010; Accepted on 28 April 2011)

\begin{abstract}
The Hydrozetes fauna was investigated at the edges of 4 ponds and pools with acid water in southern Poland. Mites of this genus achieved the highest mean abundance $\left(6 \times 10^{4} \mathrm{ind} . / \mathrm{m}^{2}\right)$ at a pond in the Tatra National Park (Staw Toporowy Niżni; $\mathrm{pH}=3.9 ; 1089 \mathrm{~m}$ a.s.1.). H. confervae dominated there (98\%), accompanied by H. octosetosus and H. lacustris. The same species were also present at a nearby pond (Staw Toporowy Wyżni; pH 3.9; 1120 m a.s.1.), but in significantly lower numbers. In the bogs of the Orawa-Nowy Targ Basin, at the edge of pool in Kaczmarka (pH 3.6; 650 m a.s.1.), H. lacustris and H. octosetosus were present, and the former species dominated (73\%). The latter species is interesting, because it was not recorded in Europe until recently. At the other pool, in Łysa Puścizna ( $\mathrm{pH} 4.5 ; 650 \mathrm{~m}$ a.s.l.), only H. lacustris was present. The lower abundance and species richness of Hydrozetes at the bog pools in the Orawa-Nowy-Targ Basin, in comparison to the Tatra National Park, was probably caused by poorer water conditions, due to more advanced succession, peat exploitation and disturbed water conditions in the Basin.
\end{abstract}

Keywords: Hydrozetes, Acari, Oribatida, bog, Sphagnum

\section{INTRODUCTION}

Hydrozetes is an aquatic genus represented in Europe by 7 species (SENICZAK et al. 2007, 2009; SENICZAK \& SEnICZAK 2008, 2009) that live in lakes, ponds, and slowly flowing water (Weigmann 2006; Weigmann \& Deichsel 2006). Two of them [H. confervae (Schrank, 1781) and H. thienemanni Strenzke, 1943] reproduce bisexually, while the others [H. lacustris (Michael, 1882), H. lemnae (Coggi, 1897), H. longisetosus S. Seniczak \& A. Seniczak, 2009, H. octosetosus Willmann, 1932 and $H$. parisiensis Grandjean, 1948] are parthenogenetic and reproduce by thelytoky (Grandjean 1948; SeniczaK et al. 2009). 
The ecology of Hydrozetes is rather poorly known; the best studied is H. lemnae, but some studies concerned also $H$. confervae, $H$. lacustris, and $H$. thienemanni (reviewed by SENICZAK 2011a). Better ecological knowledge on Hydrozetes could make them a powerful tool in bioindication (SENICZAK 2011a), palaeoecology, and related sciences (ERICKSON \& Platt 2007). In Poland, ecological studies of aquatic and semiaquatic Oribatida, including Hydrozetes, concerned mostly the northern part of the country (e.g. RAJSKI 1961; SENICZAK et al. 2006; SENICZAK 2011b, c). The aim of this research was to investigate the genus Hydrozetes in the southern part of Poland.

\section{MATERIAL AND METHODS}

\section{Study area}

Four bodies of water in southern Poland were selected: two ponds, Toporowy Staw Wyżni (TW) and Toporowy Staw Niżni (TN), both located in the Tatra National Park, as well as two pools, Łysa Puścizna (LP) and Kaczmarka (K), both situated in the bogs of the Orawa-Nowy-Targ Basin (Kotlina Orawsko-Nowotarska).

Pond TW is located at $49^{\circ} 16^{\prime} 46^{\prime \prime} \mathrm{N} ; 20^{\circ} 01^{\prime} 48^{\prime \prime} \mathrm{E}$, at the altitude of $1120 \mathrm{~m}$, in a bog surrounded by spruce forest. The pond has an area of 0.3 ha and $\mathrm{pH} 3.9$. At the pond edges, the dominant Sphagnum species were accompanied by Oxycoccus palustris Pers., Andromeda polifolia L., Drosera rotundifolia L., Eriophorum vaginatum L., Carex limosa L. and C. pauciflora Lighft. A characteristic species for TW was Pinus mugo Turra, which was not found in lower zones (Mirek 1996).

Pond TN (49 $\left.17^{\prime} 02^{\prime \prime} \mathrm{N}, 20^{\circ} 01^{\prime} 52^{\prime \prime} \mathrm{E}\right)$ has an area of 0.6 ha and is located in the lower subalpine zone, at $1089 \mathrm{~m}$ a.s.l. It is surrounded by spruce forest. The water in the pond is acid (pH 3.9) and Sphagnum species dominate at its edges (MIREK 1996). An interesting plant species is Sparganium angustifolium F., first found there in 1951, and earlier known only from one site - Rohackie Ponds in Slovakia (PiĘKoś-MirkowA 1982).

Two pools of the Orawa-Nowy-Targ Basin, LP (49 $25^{\prime} 47^{\prime \prime} \mathrm{N}$; $\left.19^{\circ} 42^{\prime} 50^{\prime \prime} \mathrm{E}\right)$ and $\mathrm{K}\left(49^{\circ} 26^{\prime} 15^{\prime \prime} \mathrm{N}\right.$; $\left.19^{\circ} 54^{\prime} 25^{\prime \prime}\right)$, are situated at ca. $650 \mathrm{~m}$ a.s.l. Both pools had area of ca. $2 \mathrm{~m}^{2}$; the pool $\mathrm{K}$ is located in a bog of 3.5 ha and water there is more acid (pH 3.6) than in pool LP ( $\mathrm{pH} 4.5)$, which is located in bog of area ca. 1.2 ha. Pools are permanently water-filled basins in bog that appear after the peatland was formed (RYDIN \& Jeglum 2006). At the edges of both pools, Sphagnum species dominated: S. fallax (Klinggr.) Klinggr, S. magellanicum Brid., S. rubellum Wils., S. tenellum (Brid.) Brid., and S. papillosum H. Lindb. They were accompanied by Drosera rotundifolia L., Empetrum nigrum L., Oxycoccus quadripetalus Hill, Ledum palustre L., Vaccinium uliginosum L., V. myrtillus L., V. vitis-idaea L., Eriophorum vaginatum L., and E. gracile W.D.J. In the tree layer, Pinus silvestris L. dominated. In the parts of Kaczmarka bog that was earlier exploited, Calluna vulgaris L. and Polytrichum commune Hedw. were abundant. Their occurrence indicates a disturbed water balance and a decrease in ground water level (Koczur 2007). In the bog of Łysa Puścizna, pine trees were planted ca. 15-20 years ago, which also disturbed the local water conditions (personal communication from Dr A. KoczUR). 


\section{Mite analyses}

From the edges of each pond and pool, 10 samples of Sphagnum mosses (each $100 \mathrm{~cm}^{2}$ in area and $5 \mathrm{~cm}$ deep) were taken on 21 September 2009. The mites were extracted in modified Tullgren funnels, and Hydrozetes species were identified, including the juvenile stages, following SENICZAK et al. (2009).

We assessed the abundance $(A)$ and percentage contributions of particular species among Hydrozetes. The basic statistical analyses included the minimum, maximum, mean values, and standard deviation. For subsequent statistical analyses, the values were log-transformed LN (x+1) (BERTHET \& GERARD 1965; MCDONALD 2009; ŁOMNICKI 2010). The normality of the distribution was tested with the KolmogorovSmirnov test, and the equality of variance in different samples, with the Levene test. When the assumption of normality or equality of variance was not met, the nonparametric Kruskal-Wallis test was used, followed by the Mann-Whitney $U$ test. All statistical calculations were carried out with STATISTICA 8.0 software.

\section{RESULTS}

The highest abundance of Hydrozetes, both of adults and juveniles, was found at pond TN in the Tatra National Park, and differed significantly from all the other bodies of water (Table 1). Three Hydrozetes species were present there, but H. confervae was most abundant (almost $6 \times 10^{4}$ ind. $/ \mathrm{m}^{2}$ ) and constituted over $98 \%$ of all Hydrozetes mites. Juveniles of this species were numerous and accounted for over $30 \%$ of the extracted population. Like other Hydrozetes species, H. confervae lived in aggregations and its abundance varied a lot among samples. This applies especially to its juveniles $\left(0.37-5.58 \times 10^{4}\right.$ ind. $\left./ \mathrm{m}^{2}\right)$. At pond $\mathrm{TN}, H$. octosetosus was the second most abundant Hydrozetes species, followed by H. lacustris. Similarly, at pond TW, H. confervae dominated among Hydrozetes, accounting for $87 \%$ of these mites, but its density was lower than $10^{3}$ ind. $/ \mathrm{m}^{2}$, and the contribution of juveniles was only $10 \%$. This species was accompanied by $H$. octosetosus (which constituted $10 \%$ of all Hydrozetes mites) and $H$. lacustris, but both species were significantly less abundant there than at pond $\mathrm{TN}$.

At pool K of the Orawa-Nowy-Targ Basin, 2 species of Hydrozetes were present. $H$. lacustris was more abundant than $H$. octosetosus, and constituted $73 \%$ of these mites. The total density of Hydrozetes at this pool was higher than at pool LP. At the latter pool only $H$. lacustris was present. The juveniles of $H$. lacustris accounted for ca. $30 \%$ of all Hydrozetes mites at pool LP and $10 \%$ at pool K.

\section{DISCUSSION}

All species of the genus Hydrozetes are aquatic and have many interesting adaptations to life in water or at its margins (BEHAN-Pelletier \& EAMER 2007; SCHATZ \& BEHan-Pelletier 2008). Some Hydrozetes species, like H. lemnae and H. thienemanni, occupy mainly eutrophic water bodies with neutral pH (STREnzKe 1952; SeniczaK 2011c). For example, $H$. thienemanni was found at the banks of the Bug River in south-eastern Poland (ŻBIKOwSKA-ZDUN et al. 2006) and was very abundant at 


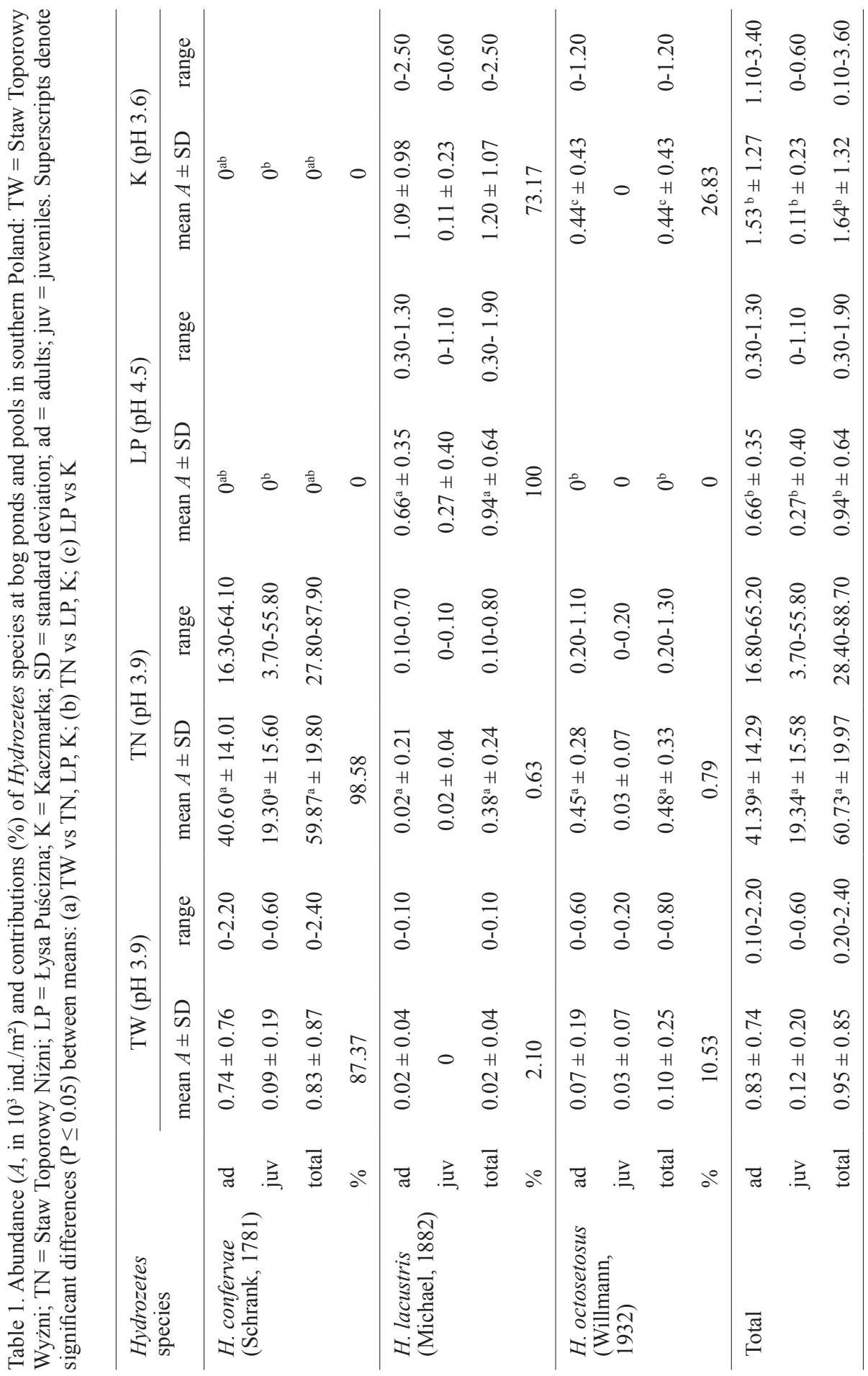


a forest pond with neutral $\mathrm{pH}$ in the Tuchola Forest (Bory Tucholskie) in northern Poland (SENICZAK 2011c). In contrast, H. lacustris prefers very acidic water (WALGRAM 1976; Weigmann 2006; Weigmann \& Deichsel 2006) and is often found on floating Sphagnum moss and algae (Willmann 1931; Popp 1962; Weigmann 2006; WeigmanN \& Deichsel 2006). WalgRam (1976) observed in Austria that at pH 3.0-3.5, 100\% of Hydrozetes mites belonged to $H$. lacustris, while at $\mathrm{pH} 4.0-4.5$, only $95 \%$. However, this observation is not confirmed in our study, as H. lacustris constituted $100 \%$ of Hydrozetes in the pool with $\mathrm{pH} 4.5$, and $53 \%$ in more acidic water $(\mathrm{pH} \mathrm{3.6),} \mathrm{where} \mathrm{it}$ was accompanied by H. octosetosus. Also at the ponds with acidic water (ca. pH 5.0) in Bergen area, Norway, H. lacustris occurred together with H. octosetosus, and was more or less abundant than the latter species (SENICZAK et al. 2007, 2010). In the Tuchola Forest, this species was present with H. longisetosus and H. octosetosus (SENICZAK et al. 2007, SENICZAK 2011b). H. octosetosus was described by Willmann (1932), but it is probably overlooked by many authors in ecological investigations, as it was not recorded in Europe until recently (SENICZAK et al. 2007, 2010; SENICZAK 2011b).

Hydrozetes confervae was found less frequently in northern Germany than $H$. lacustris (WILLMANN 1931). It was also absent from forest ponds in northern Poland (SEniczak et al. 2006; SeniczaK 2011b,c). In Russia it was recorded only in eutrophic bogs near Moscow, in contrast to H. lacustris, which occurred in oligotrophic bogs (DruK 1982). H. confervae was found mainly in filamentous algae of the family Confervaceae (= Ulotrichaceae) (Schrank 1781; OudEmans 1897) and on duckweed (Weigmann 2006; Weigmann \& Deichsel 2006; Seniczak et al. 2009). Interestingly, in this study it lived in Sphagnum mosses at pond edges in the Tatra National Park and was the most abundant Hydrozetes species there.

To sum up, the Hydrozetes fauna of the acid ponds and pools in southern Poland differed from that in northern Poland (studied earlier). H. longisetosus in northern Poland dominated among Hydrozetes mites, but was absent in the south. In contrast, $H$. confervae was absent from ponds in northern Poland but abundant in the south. The lower abundance and species richness of Hydrozetes at the pools in the OrawaNowy-Targ Basin than in the ponds in the Tatra National Park, can be explained by poorer water conditions, due to the more advanced succession, and disturbed water conditions in the Basin, due to peat extraction (pool K) and tree planting (pool LP).

\section{REFERENCES}

Behan-Pelletier V. M., Eamer B. 2007. Aquatic Oribatida: adaptations, constraints, distribution and ecology. In: Acarology XI: Proceedings of the International Congress (Morales-MAlacara J. B., Behan-Pelletier V. M., Ueckermann E., Pérez T. M., Estrada-Venegas E. G., BADII M., Eds.), pp. 71-82, Instituto de Biología, Facultad de Ciencias, Universidad Nacional Autónoma de México; Sociedad Latinoamericana de Acarología, México.

Berthet P., Gerard G. 1965. A statistical study of microdistribution of Oribatei (Acari). Part I. The distribution pattern. Oikos 16: 214-227.

DruK A. JA. 1982. Pancirnye klešči nekotorych tipov bolot Moskovskoj oblasti [Beetle mites of certain types of bogs in the Moscow region]. In: Počvennyje bespozvonočnyje Moskovskoj oblasti (Giljarov M. D., Ed.), pp. 72-77, Izdatel'stvo 'Nauka' Moskva (in Russian). 
ERICKSON J. M., Platt R. B. JR. 2007. Oribatid mite studies. In: Encyclopedia of Quaternary science (Elias S., Ed.), pp. 1547-1566, Elsevier, London.

Grandjean F. 1948. Sur les Hydrozetes (Acariens) de l'Europe occidentale [About Hydrozetes (Acariens) of the Western Europe]. Bull. Mus. nat. Hist. natur. (2) 20: 328-335 (in French).

Koczur A. 2007. Wełnianka delikatna Eriophorum gracile W.D.J Koch w Kotlinie Orawsko-Nowotarskiej [Slender cottongrass Eriophorum gracile W.D.J Koch in the Orawa-Nowy-Targ Basin (Kotlina Orawsko-Nowotarska)]. Chrońmy Przyrodę Ojczystą 63: 48-57 (in Polish).

ŁoMNICKI A. 2010. Wprowadzenie do statystyki dla przyrodników [Introduction to statistics for biologists]. PWN, Warszawa (in Polish).

McDonald J. H. 2009. Handbook of biological statistics, 2nd ed. Sparky House Publishing, Baltimore, Maryland.

Mirek Z. 1996. Przyroda Tatrzańskiego Parku Narodowego [Nature of the Tatra National Park]. Tatrzański Park Narodowy, Kraków-Zakopane (in Polish).

Oudemans A. C. 1897. Notes on Acari. Tijdschr. Ent. 39: 175-187.

Pį̨Koś-Mirkowa H. 1982. Flora synantropijna w otoczeniu obiektów turystycznych w Tatrach [Synantropic flora in the surroundings of the tourist objects in the Tatra]. Studia Naturae ser. A 22: 79-132 (in Polish).

Popp E. 1962. Semiaquatile Lebensräume (Bülten) in Hoch- und Niedermooren. (2. Teil: Die Milbenfauna) [Semi-aquatic habitats (hummocks) of bogs and fens. (Part 2. The mite fauna)]. Int. Rev. ges. Hydrobiol. 47: 533-579 (in German).

RAJSKI A. 1961. Faunistic-ecological investigations on moss mites (Acari, Oribatei) in several plant associations. I. Ecology. Bull. Soc. Amis. Sc. Lettr. Poznań, ser. B. 25: 123-283.

Rydin H., JegLum J. K. 2006. The biology of peatlands. Oxford University Press.

Schatz H., Behan-Pelletier V. M. 2008. Global diversity of oribatids (Oribatida: Acari: Arachnida). Hydrobiologia 595: 323-28.

SCHRANK F. P. 1781. Enumeratio insectorum Austriae indigenorum. Augustae Vindeliciorum.

SenicZAK A. 2011a. Mites (Acari) of the shores forest lakes and ponds in northern Poland, with species analysis of Oribatida. Wyd. Uniwersytetu Technologiczno-Przyrodniczego, Bydgoszcz.

Seniczak A. 2011b. Oribatid mites (Acari, Oribatida) and their seasonal dynamics in a floating bog mat in Jeziorka Kozie Reserve, Tuchola Forest (Poland). Biological Lett. 48: 3-11.

SenicZAK A. 2011c. The occurrence of Hydrozetes (Acari, Oribatida) at some water reservoirs near Bydgoszcz. Biological Lett. 48: 185-192.

Seniczak S., Norton R. A., Seniczak A. 2009. Morphology of Hydrozetes confervae (Schrank, 1781) and H. parisiensis Grandjean, 1948 (Acari: Oribatida: Hydrozetidae), and keys to European species of Hydrozetes Berlese, 1902. Zool. Anz. 248: 71-83.

SenicZak A., SenicZaK S. 2008. Setal variability of Hydrozetes lemnae (Coggi, 1897) and H. thienemanni Strenzke, 1943 (Acari: Oribatida: Hydrozetidae). Biologia 63: 677-683.

Seniczak S., Seniczak A. 2009. Hydrozetes longisetosus sp. nov. (Acari: Oribatida: Hydrozetidae) the most primitive European species of Hydrozetes from Poland. J. Nat. Hist. 43: 951- 971.

Seniczak A., Seniczak S., Nowicka A. 2006. Roztocze (Acari) strefy brzegowej dwóch jezior śródleśnych o różnej jakości wody, w Borach Tucholskich [The mites (Acari) of the water edge of two forest ponds with different water quality in the Tuchola Forest]. Zootechnika 36: 31-38 (in Polish).

Seniczak S., Solhøy T., Seniczak A. 2007. Systematic status of Hydrozetes octosetosus Willmann, 1932 (Acari: Oribatida: Hydrozetidae) in the light of ontogenetic and ecological studies. J. Nat. Hist. 41: 2081-2098.

Seniczak A., Solhøy T., Seniczak S., Riva-Caballero A. 2010. Species composition and density of the oribatid fauna (Acari, Oribatida) at two lakes in the Fløyen area, Bergen, Norway. Biological Lett. 47: 11-19.

StrenzKe K. 1952. Untersuchungen über die Tiergemeinschaften des Bodens: Die Oribatiden und ihre Synusien in den Böden Norddeutschlands [Studies on the animal communities of the soil. 
The oribatid mites and their synusia in the soils of northern Germany]. Zoologica 104: 1-173 (in German).

Walgram M. 1976. Über die Verbreitung der wasserbewohnenden Hornmilbengattung Hydrozetes Berlese 1902 (Acari, Oribatei) in Österreich [About the distribution of aquatic oribatid species Hydrozetes Berlese 1902 (Acari, Oribatei) in Austria]. Mitt. Naturwiss. Ver. Steiermark 106: 215-219 (in German).

Weigmann G. 2006. Hornmilben (Oribatida) [Oribatid mites (Oribatida)]. Die Tierwelt Deutschlands, vol. 76, Goecke. \& Evers, Keltern (in German).

Weigmann G., Deichsel R. 2006. 4. Acari: Limnic Oribatida. In: Süßwasserfauna von Mitteleuropa, 7/2-1 (Brauer A., Ed.), pp. 89-112, Elsevier, Spektrum Akademischer Verlag.

Willmann C. 1931. Moosmilben oder Oribatiden (Cryptostigmata) [Moss mites or Oribatids (Cryptostigmata)]. In: Die Tierwelt Deutschlands (Dahl F., Ed.), Bd. 22, vol. 5, pp. 79-200, Gustav Fischer, Jena (in German).

Willmann C. 1932. Oribatiden aus dem Moosebruch [Oribatids from the Moosebruch]. Arch. Hydrobiol. 23: 333-347 (in German).

Ż́ikowska-Zdun K., Piksa K., Watrak I. 2006. Diversity of mites (Acari: Oribatida) in selected microhabitats of the Bug River Protected Landscape Area. Biological Lett. 43: 277-286. 